\title{
VARIOUS USES OF ADDRESS FORMS IN JAPANESE SOCIETY IN PERSPECTIVE OF SOCIOLINGUISTICS AND ANTHROPOLOGICAL LINGUISTICS
}

\author{
Stephanus Mangga \\ Gadjah Mada University, Yogyakarta \\ Pagal1776@yahoo.com
}

\begin{abstract}
Every social and cultural community has its own appropriate ways and forms to address someone. Addressing someone in appropriate way is a sign of respect and honorific. This paper describes various uses of address forms in Japanese society. Japanese society has four address forms in common: -chan, -kun, -san, and -sama forms. They are related to social dimensions: social distance scale, status scale, and formality scale. In addition, background of various uses of the forms in perspective of sociolinguistics and anthropological linguistics is thought as reflection of cultural aspects which exist in Japanese society. Those are politeness-deference aspects, seniorityjunior aspects, and insider-outsider aspects. Finally, there are two major findings of this study: (1) various uses of address forms in Japanese society and cultural relation to social dimensions, (2) various uses of address forms in Japanese society and Japanese culture as a reflection of cultural aspects.
\end{abstract}

Setiap komunitas sosial dan budaya memiliki cara-cara dan bentukbentuknya sendiri untuk memanggil seseorang. Memanggil seseorang dengan cara yang tepat adalah sebagai tanda penghargaan dan penghormatan. Penelitian ini adalah tentang perbedaan penggunaan bentuk panggilan dalam masyarakat Jepang. Secara umum, masyarakat Jepang memiliki empat bentuk panggilan yaitu chan, -kun, -san, dan-sama. Perbedaan dalam menggunakan bentuk tersebut dikaitkan dengan dimensi sosial contohnya skala jarak sosial, status sosial, dan formalitas. Sedangkan dalam perspektif sosiolinguistik dan linguistik antropologi, latar belakang perbedaan dalam menggunakan bentuk-bentuk sapaan adalah sebagai refleksi aspek budaya yang ada dalam masyarakat Jepang seperti aspekaspek kesopanan-penghargaan, aspek-aspek senioritas-junioritas, dan aspek-aspek ke dalam dan ke luar. Dari penelitian ini didapat dua temuan utama: (1) perbedaan dalam menggunakan bentukbentuk sapaan di masyarakat Jepang dan budaya yang berkaitan dengan dimensi social, (2) perbedaan dalam menggunakan bentukbentuk sapaan dalam masyarakat dan budaya Jepang sebagai refleksi aspek budaya. 
Kata kunci: bentuk-bentuk sapaan, dimensi sosial, kesopanan, penghormatan, dan aspek-aspek budaya

\section{INTRODUCTION}

In perspective of sociolinguistics and anthropological linguistics, being polite also means to address someone in an appropriate way. Although it is variable from one social community to another, but generally, "being polite means getting the linguistic expression of social distance right as far as your addressee is concerned"(Holmes 1992:300). For instance, in Japanese society, it is considered rude and impolite to address someone elder just by name without adding "san" or "sama" after the name. In this case, socially and culturally, addressing someone in an appropriate way is a sign of respect and honorific.

In addition, there have been some previous studies of address forms. For instance, Oyetade (1995) analyzed address forms in Yoruba by using sociolinguistics theory; Yang (2010) analyzed address forms of English focusing on rules and variation; and Afful (2007) studied address forms and variations among university students in Ghana. Those three studies analyze the address forms from different points while this paper explains the various uses of address forms in Japanese society in perspective of sociolinguistics and anthropological linguistics.

By this study, the writer would like to analyze and to describe two things as the objectives of this paper: (1) to analyze and to describe kinds of address forms in Japanese society, and (2) to analyze and to describe background of various uses of these address forms in perspective of sociolinguistics and anthropological linguistics.

This study uses some theories to analyze the data, among other things, address forms in Japanese proposed by Crystal (1987) which consists of -kun, chan, -san, and -sama ; social dimension by Holmes (1992) which consists of social distance scale, status scale, and formality scale; honorific system by Foley (1997); politeness proposed by Inoue (1979 cited in Foley, 1997) and deference aspect proposed by Shibatani (1990 cited in Foley, 1997); seniority - junior aspects proposed by Matsumoto (cited in Foley, 1997); and insider - outsider aspects proposed by Foley (1997) and Agha (2007).

\section{RESEARCH METHODS}

The research method of this study is library research. The writer collected the data by searching the information about variety of address forms used by Japanese from many sources such as books, internet, and movies. He also observed the daily conversation of Japanese which are related to variety of address forms, but he did not join the conversations which were done by them. Then, he transcribed the data collected from written and spoken sources related to this study and analyzed them based on the theory.

\section{RESULTS AND DISCUSSION}

The results and discussion of this study are divided into two sections. Firstly, it is about kinds of address forms in Japanese society and culture. In this section, the 
writer would like to analyze and to describe four address forms which are commonly used in Japanese society. The four address forms are a) - kun, b) chan, c) - san, and d) - sama (Crystal 1987:99). Secondly, it is about background of variety using of the address forms in Japanese society. It will be analyzed and discussed in perspective of sociolinguistics and anthropological linguistics. From view point of both perspectives, the background will be divided into three aspects: a) politeness - deference aspects, b) seniority - junior aspects, and c) insider outsider aspects.

\section{Address Forms in Japanese Society}

Like other social communities in the world, Japanese society also has its own address forms of addressing someone. It is usual for Japanese people when addressing someone, to add such forms after the name of addressee. Meanwhile, it will sound rude and impolite to call upon the addressee just only by name (especially elder or superior addressee) without adding such forms after the name. According to Foley, Japanese has a system of honorific which registers the relative status entitlements of addressee against speaker (Foley 1997:319). Thus, it could be said that Japanese society has special lexemic repertoires of an honorific register in addressing someone.

As it is mentioned above, Japanese society has four address forms of addressing someone. Various uses of these four address forms were analyzed and described with social dimensions proposed by Holmes (1992) which consists of social distance scale, status scale, and formality scale. The social distance scale relates to speaker and hearer's relationships which can be described as intimate or distance between them. The status scale associates with superior or subordinate relation between speaker and hearer. The formality scale connects to the formal and informal setting.

Based on those scales, the four address forms in Japanese can be analyzed and described as follows:

\section{a) -chan}

This form is often attached to female children's names when calling them by their given names. It can also be attached to kinship terms in a childish language. In terms of social distance, the form shows intimate relationships among participants, e.g., parents address their daughter, a grandchild addresses her grandpa or grandma.

In terms of status scale, it indicates no distinction whether the speaker is superior and the addressee is subordinate. In terms of formality scale, this form is usually used in informal situation. Some examples are shown in the following table.

\begin{tabular}{|l|l|}
\hline Mika-chan & Mika (female name) \\
\hline ojii-chan & Grandpa \\
\hline obaa-chan & Grandma \\
\hline otoo-chan & Father \\
\hline okaa-chan & Mother \\
\hline oji-chan & Uncle \\
\hline oba-chan & Aunt \\
\hline
\end{tabular}




\begin{tabular}{|l|l|}
\hline onii-chan & elder brother \\
\hline onee-chan & elder sister \\
\hline
\end{tabular}

b) - kun

This form is used to address men who are younger or the same age as the speaker. According to Crystal (1987:99), this form is used for men only, but a male actually might address female inferiors by using "- kun" usually in schools or companies. It can be attached to both surnames and given names. It is less polite than "- san". It is not used between women or when addressing one's superiors (it will sound impolite and rude).

In terms of social scale, the form shows intimate relationships among participants. For example, Yamada and Honda are the same age and friends. Yamada can address Honda by "Honda kun"; in the same way Honda can also address Yamada by "Yamada kun". In terms of status scale, for example a teacher addresses a student and an elder addresses a younger, it indicates the addressee (student, younger) is subordinate or low status. Thus, it is impolite or rude to address a teacher or an elder by using "-kun". In terms of formality, it indicates both formal (in school or office or parliament meeting) and informal (outside school or office).

c) $-\operatorname{san}$

This form can be used with both male and female names, and with either surnames or given names. It can also be attached to the name of occupations and titles.

In terms of social distance, the form shows both intimate and distant relationships among participants. For example, a child can address his/her parents by using "otoo-san" (father) and "okaa-san" (mother). In this case, it shows intimate among participants. But when it is used to address somebody else's parents, it indicates distance and respect. In terms of social scale, it indicates the addressee is more superior or has a higher status than the speaker. In terms of formality scale, this form can be used in both formal and informal situations. Some other examples of using the form can be seen in the following table.

\begin{tabular}{|l|l|l|}
\hline Surname & Yamada san & Mr. Yamada \\
\hline Given name & Yoko san & Miss. Yoko \\
\hline Occupation & Honya san & Bookseller \\
& Sakanaya san & Fishmonger \\
\hline Title & Shichou san & Mayor \\
& Oisha san & doctor \\
& Bengoshi san & Lawyer \\
\hline
\end{tabular}

d) - sama

This form can be attached to the family name, the given name or the full name. It is more polite than "san", though it is rarely used in a casual conversation. It is used with the name of the addressee on a letter and also when addressing a customer.

In terms of social distance, it indicates a distance between the speaker and the addressee. For instance, addressing a royal family, a boss of company, a prime minister, customers (in Japan, customers being treated like a king), and others. In 
terms of status scale, it indicates the addressee is more superior or has a higher status than the speaker. In terms of formality scale, it is common to use the form in a formal situation. For instance, in a formal meeting, especially a meeting among the boss of companies, it is unusual to address somebody just by using "-san" form. If it happens, the speaker can be judged as impolite, rude, and arrogant.

\section{Background of Various Uses of Address Forms in Japanese Society}

In perspective of sociolinguistics and anthropology linguistics, various uses of address forms in Japanese society, as described above, reflects at least three aspects of way of thinking which exist in culture of Japanese society.

\section{Politeness - deference aspects}

Japanese society has a system of honorific which registers the relative status entitlements of addressee against speaker. This notion implicates politeness and deference aspects which exist and live in the society. Even though Thomas (in Fukushima, 2003:55) argued that deference (it refers to the respect we show other people) is different from politeness (it is a more general matter of showing consideration to others), but in the case of using address forms, deference is connected with politeness. In this case, it indicates either impolite or non-deferential to address someone, especially an elder just by name without adding honorific suffix "san" or "sama" after the name. In addressing someone elder or superior, Japanese speaker indicates deference (Shibatani, 1990:377, in Foley, 1997:319) and politeness (Inoue, 1979:287, in Foley, 1997:320) to the addressee. Thus, it could be said that, various uses of address forms of "-san" or "-sama" is reflection of both politeness and deference aspects which exist in culture of Japanese society.

\section{Seniority - junior aspects}

In many situations of communication, Japanese people really observe seniorityjunior aspects. That is the writer's experience when he lived in Japan. According to Matsumoto (in Foley, 1997:274), “A Japanese generally must understand where s/he stands in relation to other members of the group or society, and must acknowledge his/her dependence on others. Acknowledgement and maintenance of the relative position of others, rather than preservation of an individual's proper territory, governs all social interaction."

In terms of addressing someone, it is a social rule to acknowledge who is senpai 'senior' and who is kouhai 'junior'. Kouhai, when addressing senpai, naturally uses "-san" or "-sama" form. On the contrary, senpai can address kouhai just by using "-kun" or "-chan" form. It also happens in communication between a superior or an elder and a subordinate or a younger. A superior or an elder can address a subordinate or a younger by using "-kun" form; but it is rude and impolite to address an elder or a superior by using "-kun" form. "In traditional workplace settings, a junior employee will normatively address a senior colleague by using a title, e.g., ...Oisha san 'Doctor', Kachō san 'Section Chief' ...; the senior colleague will, in turn, use the same title for self-reference...thus employing address inversion as a part of larger pattern that maintains the self's higher status." (Agha, 2007:360). Thus, it could be said that various uses of address forms in Japanese society is 
reflection of seniority-junior aspects of the culture or way of thinking.

\section{$\underline{\text { Insider - outsider aspects }}$}

When addressing someone, Japanese people also consider the aspects of uchi no hito 'insider' and soto no hito 'outsider' (Foley, 1997:274, 321; Agha, 2007:329). Uchi no hito refers to "in group of people", like family members, same work of members, same company of members, etc. And soto no hito refers to "out group of people"; people outside the mentioned categories.

In case of addressing someone, in group of people can address each other by using "-kun" or "-chan" form. But it is impolite and rude to address out group of people (includes foreigners) by using these forms. To address someone outsider, people normally use "-san" or "-sama" form. Thus, it could also be said that various uses of address forms in Japanese society is a reflection of insider - outsider aspects of the culture or way of thinking.

\section{CONCLUSION AND SUGGESTION}

This part is divided into two parts: the first is conclusion of this study and the second is the suggestion for further study.

\section{Conclusion}

Based on various uses of address forms in Japanese society described above, it can be concluded that first Japanese society has four address forms in common. Those are a) - chan, b) - kun, c) - san, and d) - sama and various uses of these forms related to social dimensions, i.e., social distance scale, status scale, and formality scale. Second, in perspective of sociolinguistics and anthropology linguistics, the background of various uses of the address forms in Japanese society is a reflection of cultural aspects. Those are politeness - deference, seniority - junior, and insideroutsider aspects.

\section{Suggestion}

This study focuses on variety of address forms in Japanese from perspective of sociolinguistics and anthropological linguistics, so the next researchers who want to do the research in address forms can analyze other aspects such as the ways Japanese in answering the address forms, and the pragmatic aspects of address forms.

\section{REFERENCES}

Afful, Joseph Benjamin Archibald. 2007. "Address Forms and Variation among University Students in Ghana". In Nordic Journal of African Studies 16 (2): 179-196 (2007). South Africa: University of the Witwatersrand.

Agha, Asif. 2007. Language and Social Relations. New York: Cambridge University Press.

Aziz, E. Aminudin. 2005. "Konsep Wajah dan Fenomena Kesantunan Berbahasa 
Pada Masyarakat Cina Modern: Kasus Shanghai". In Jurnal Ilmiah Masyarakat Linguistik Indonesia, 23, 2, pp. 205-212.

Chaer, Abdul. 2011. Ragam Bahasa Ilmiah. Jakarta: Rineka Cipta.

Crystal, David. 1997. The Cambridge Encyclopedia of Language. New York: Cambridge University Press.

Foley, William A. 1997. Anthropological Linguistics: An Introduction. England: Blackwell.

Fukushima, Saeko. 2003. Request and Culture: Politeness in British English and Japanese. German: Peter Lang.

Holmes, Janet. 1992. An Introduction to Sociolinguistics. New York: Longman. http://japanese.about.com/library/blqow38.htm, accessed on December 21, 2011. http://japanese.about.com/bllesson18.htm, accessed on December 21, 2011.

Murata, Miyoshi (Ed.). 2005. Bunpo no Jikang ('Time's Grammar'). Tokyo: Shibundo.

Oyetade, Solomon Oluwole. 1995. "A Sociolinguistic Analysis of Address Forms in Yoruba". In Journal of Language in Society Vol. 24, No. 4 (Dec. 1995), pp. 515-535. United States of America: Cambridge University Press

Kiyose, Gisaburo N. 1993. A New Approach to Japanese Grammar. Tokyo: ŌFŪ.

Rahayu, Ely Triasih. 2011. "Sistem dan Fungsi Keigo dalam Perusahaan Jepang". In Kumpulan Prosiding Seminar Internasional "Strategi Pembelajaran Bahasa Jepang di Sekolah Menengah dan Perguruan Tinggi di Indonesia" (Purwokerto, 28-30 October 2011), pp. 177-186.

Sumarsono, M. 2011. Sosiolinguistik. Yogyakarta: SABDA.

Tafarodi, Romin W., Sarah C. Shaughnessy, Susumu Yamaguchi, and Akito Murakoshi. 2011. "The Reporting of Self-Esteem in Japan and Canada". In Journal of Cross Cultural Psychology 42 (1) 155-164. America: SAGE.

Takashi, Masuoka and Yukinori Takubo. 1989. Kiso Nihonggo Bunpo (Japanese Basic Grammar). Tokyo: Kuroshio.

Tanaka, Lidia. 2004. Gender, Language, and Culture: A Study of Japanese Television Interview Discourse. Amerika: John Benjamins B.V.

Thosiko, Tanaka. 1992. Guidance on Japanese Grammar. Tokyo: Shidaibunkyo.

Yang, Xiaomei. 2010. “Address Forms of English: Rules and Variation”. In Journal of Language Teaching and Research Vol. 1, No. 5, pp. 743-745, September 2010. Finlandia: Academy Publisher 